\title{
GIS IN SOIL EROSION - MODELLING OF VICTORIA - RANDENIGALA CATCHMENT, SRI LANKA
}

\author{
H G Gunawardana \\ Forest Department, Battaramulla.
}

Lind and water resoures are the backbones of an agricultural-based country like ours. Their role in national productivity, however, depends on how we manage them. Appropriate management alternatives are the result of technically sound decisions. With the aid of a resource-based computer program like SPANS-GIS. such decisions are readily drawn atter input variables are integrated into the program.

Victoria-Randenigala area was chosen in this work, as it is the major catchment of the Mahaweli River which stretches the entire central hill country. With the use of SPANSGIS, information on erodibility, erosion potential, catchment natural stability, strict protective areats and recommended forms of land-use were readily identified. Details of the lindings show that $84 \%$ of the area lies over 1,000$)$ ft. Comour and $19 \%$ at $>30 \%$ slope class. Ahout $43 \%$ of the catchment area is at high erodibility risk despite $39 \%$ existing forest cover, due to land degradation. Only $36 \%$ of the catchment area is considered naturally stable. Hence protection priority should be given to $68 \%$ of the catchment area. To conserve the catchment, $31 \%$ of the area must be afforested and $40 \%$ must be planted with perennial crops or forest species.

SPANS-GIS proved useful in identifying key elements necessary in managing VictoriaRindenigala caltchment. It is a valuable tool in providing information that helps man in managing land and waller resources. 